\title{
Revealing the Sharia Accounting Practice at East Java MSMEs to Support Halal Business Climate
}

\author{
Dhika Maha Putri ${ }^{1}$, Sheila Febriani Putri ${ }^{2}$, Dian Syariati ${ }^{3}$, Imamul Huda ${ }^{4}$, Mahirah $^{5}$ \\ \{dhika.maha.fe@um.ac.id $\left.{ }^{1}\right\}$ \\ Universitas Negeri Malang, Indonesia ${ }^{1,2,3,4}$ \\ Universiti Malaysia Terengganu, Malaysia ${ }^{5}$
}

\begin{abstract}
The essence of life in Islam is the condition of a person when he or she returns to God or we know as the statement of innaalillaahiwainnaailaihiraaji-uun, which means that we belong to God, and to Him, we return. Sharia accounting does not only function as an earthly instrument but also as an instrument of prayer and dhikr to awaken divine awareness. With Sharia accounting, financial management is no longer a separate element from the spiritual concept so that its practice can help one to remain istiqomah until the time of return to Allah SWT. Sharia accounting is very important in business management because it makes someone always try to be honest and responsible in every decision making. Through sharia accounting, MSMEs owners have the motivation to maintain business quality, therefore they can maintain their business continuity. Therefore, the spirit of sharia accounting practices needs to be grounded in MSME actors. Through the data collected by interviews and focus group discussions, this study describes the understanding and practice of sharia accounting at MSMEs in East Java. By using the information obtained from this study, it is hoped that in the future appropriate strategies will emerge to encourage MSMEs to practice sharia accounting. In fact, MSMEs don't understand much about what is sharia accounting and still find it difficult to practice it in financial management. This condition occurs because there are a very few guidelines that describe sharia accounting practices. The results of the study suggest the need for a sharia accounting practice model and guidelines according to the conditions of the MSME. The implementation of sharia accounting is believed to be able to improve the quality of MSME financial management because it is accompanied by divine awareness in every business decision.
\end{abstract}

Keywords: Sharia Accounting, Financial Management, MSMEs, Practice, Guidelines.

\section{Introduction}

Halal business receives positive responses from various parties. A study on non-muslim behavior towards halal food products shows good acceptance related to health, food safety, hygiene and food quality aspects [1]. The same results are also found in halal tourism and halal pharmaceuticals [2][3]. Aziz and Chok [4] assert that halal awareness, halal certification, marketing promotion, and brand positively affect the purchase intention of non-muslim consumers. Based on the data compiled by Thomson Reuters [5], the spending value for halal food reached US\$2.1 trillion in 2017 and it is estimated to increase to US\$3 trillion by 2023. Indonesia is responsible for $10 \%$ in the expenses at that corresponding year (Indonesia Halal Lifestyle Center, 2018). This phenomenon implies that halal business can become a new 
economic weapon. The interesting point does not only lie on the fantastic amount, but also divine awareness beyond these figures. Business is not only about profit but also the fulfillment of halal or sharia aspect.

Biancone and Radwan [6] noted the importance of Italian SME to participate in sharia industry through changes in business or industrial sector as well as changes in financial structure. MSME participation into this sector is one of the main strategies of Indonesian government in dealing with halal business climate (The Ministry of National Development Planning, 43). From accounting perspective, the use of Syariah accounting is relevant to the entities involved in Sharia transactions. It is because the paradigm, principle, and characteristics underlying Sharia transactions is different from conventional transactions. The characteristics exclude riba, zalim, maysir, gharar, and haram practices. With these characteristics, the business activities are aimed at meeting the essential welfare both in material and spiritual. The same opinion is suggested by Alim [7] who refers maqhasid sharia as the conception of Sharia accounting. Triyuwono [8] states that Sharia accounting is an art in conveying information as a mean of prayer and dhikr to meet economic, psychological, and spiritual needs as well as rising divine awareness. In line with those ideas, Pratama et al. [9] describes two versions of sharia accounting reviewed from its fundamental purpose of financial statements. The first version is that financial statements provide information (financial and nonfinancial) and accountability (horizontal and vertical). The second version is that financial statements provide information, peacefulness, love and caring, as well as stimulating divine awareness. In brief, for MSMEs, Sharia accounting is a business instrument and supporting the search for the self-essence and life goals. Sharia accounting allows the financial management to integrate with the spiritual concept, so that its practice can help one to remain istiqomah until the time of return to Allah SWT as essentially, we belong to God, and to God, we return. As taught, it is innaalillaahiwainnaailaihiraaji-uun.

Unfortunately, the discussion about Sharia accounting practice in MSMEs only revolves around financial management which most of the time materialistic [6]. This study explores the integration of financial management and spiritual concept that becomes the spirit of Sharia accounting practice. This study is not limited to the procedure in making financial statements, but also search for Sharia accounting as an instrument of prayer and dhikr to awaken divine awareness. This occurs since the structure and attitude of an organization is influenced by external and internal factors [10][11]. The existence of Sharia accounting is expected to improve the quality of MSMEs' financial management because it is accompanied by divine awareness in every business decision. MSMEs in East Java were chosen as the research object as it is a province with the greatest number of MSMEs [12].

\section{Research Method}

This research was conducted with a qualitative approach through case studies. The type of data used is secondary data and primary data. Secondary data is obtained from literature studies, books, research, and other sources related to this research, while primary data is collected through interviews and FGD (Forum Group Discussion) to informants who are owners of MSMEs in East Java. This research was conducted through direct interviews and FGDs with MSME owners in East Java, in order to answer the research objectives in-depth, namely collecting information related to the Islamic accounting perspective they know. In 
addition, the results of the interviews can be used as a guide in making sharia accounting records needed by MSME owners in East Java to support the creation of a halal climate.

This research was conducted during a pandemic, so the data collection through interviews and FGDs was done online. Due to the limitations of the current COVID-19 situation, personal interviews were not possible, so online interviews were conducted in FGD with informants. The online interview is a research method that uses computer-mediated communication. Just like personal interviews, online interviews usually ask participants to describe what they think or feel about an aspect [13]. Several informants who acted as informants were selected by purposive sampling from each region in East Java and adjusted to the type of business, namely MSMEs in the fields of Service, Trade, and Manufacture. There were 6 selected informants in each region of East Java in the fields of Service, Trade, and Manufacture. The criteria chosen are business owners in the field of Service, Trade, and Manufacture represented by 2 resource persons in each field. This selection is made with the hope that the information obtained can be linear in accordance with the objectives and needs of the study.

\section{Literature Review}

\subsection{MSMEs and Social Structure of Rural and Urban Communities}

Micro, Small, Medium enterprise is one of the economic activities that are quite popular in the community as the grassroots support of welfare. Some call this type of economic activity as the shadow economy [14], as it is not legally registered [15], but positively contributes to the national economic [16]. Other also refer to it is as informal economic sector. This economic sector is growing in urban and rural communities [17]. Typology and geographical features of the community do not hinder the Micro, Small, Medium Enterprises (MSMEs) to root among them [18]. The informal economic activity is proven sustainable amidst economic crisis in Indonesia [19], as for some reasons it is not significantly affected by global economic issues.

The strength of informal economic sector in the form of MSMEs has gained attention from experts to further investigate the essence of this economic activity. The characteristic mentioned above, that informal economic sector is the shadow economic [14], not registered [15], but able to support the public economic [16], are included in the general conception. This activity, in fact, can provide job opportunities for the community, not only for the owners, but also for the worker class who do not own capital [20]. Many of them are vulnerable since they do not have any access to capital [21]. So, the only way to save their financial conditions is through this informal sector along with all its consequences.

Like the two sides of the same coin, the informal economic sector comes with benefits and impacts. The benefit of informal sector is clearly to encourage the economics of the people [16]. While the impact arising from this economic activity may differ from one community to another depending on the anatomy of society. Rural community does not significantly take the advantage of informal sector. Conversely, it is growing with minimum impacts. Informal sector can bring about self-employment, and strengthen community relationship [22]. However, informal sector in rural areas has brought problems to the municipality [23], and they have to formulate the resolution such as relocation, compensation, while maintaining the city order, etc. [24][25]. In the past, rural community were likely to maintain their traditional production through agriculture, but it is now fading away [26]. In 
addition to the decreasing agricultural productivity [27], rural industrialization requires green space in agriculture [28], so it makes them prefer other income alternatives, for instance the informal sector. As the result, a great flow of urbanization could occur [29]. Villagers will flock to cities to search for formal or informal jobs [30] which leads to other dilemmatic problems [25]. The municipality has to think how they can maintain the beauty of the city while protecting the economic lives of the informal economic actors.

\subsection{Religion-Based Accounting Practice for MSMEs}

Today, there are only a few MSME actors who are able to professionally manage their business financial [31]. Accounting practice may sound strange to these MSMEs actors. The implementation of professional financial accounting is typically performed by big and formal business management. Unlike the informal MSMEs, big businesses are registered, so their financial records through accounting practice is very crucial. Besides for the accountability of the business financial, accounting practice makes the tax paid to the state accountable as well. Actually, informal business registration into the formal one has been facilitated by the government. In its practice, many informal sector actors in Indonesia do not register their business formally even though the bureaucracy is easier now [32].

\section{Results and Discussion}

As an instrument or tool, Islamic accounting can be interpreted as an art in describing financial information obtained from the transaction process. In modern accounting, transactions are recognized as physical exchanges involving goods and services. The exchange process is then expressed in monetary terms so it becomes accounting information. On the other hand, sharia accounting not only recognizes physical transactions but also mental and spiritual transactions. In Islamic accounting, every monetary exchange that occurs must be based and fenced in by the provisions of the Islamic religion. The condition of goods, location, and situation when the transaction takes place is the main thing considered in sharia accounting. Islamic accounting functions not only as an earthly instrument but also as an instrument of prayer and dhikr to awaken divine awareness. With Islamic accounting, financial management is no longer a separate element from the spiritual concept so that its practice can help one to remain steadfast until the time of returning to Allah SWT. Because the essence of life is how a person is when he returns to God.

The utilization of sharia accounting is proven to improve the performance of business entities. This is because when managing a business, the owner is always reminded of Allah SWT in every decision making. By remembering Allah SWT, organizational decisions become more focused and future-oriented. Furthermore, by applying sharia accounting business entities will always strive to maintain its quality through honest and trustworthy recording. Based on these thoughts, this study tries to examine how the sharia accounting practices of MSMEs in East Java. The research aims to reveal how the implementation of Islamic accounting and the problems that accompany it. With this research, it is expected that the pattern of the use of Islamic accounting can be interpreted comprehensively.

\subsection{The Pattern of the Use of Sharia Accounting at MSMEs in East Java}

This research was carried out by conducting a Focus Group Discussion (FGD) as well as in-depth interviews with representatives of the East Java Muslim MSME Association. Each 
representative is in charge of approximately 60 MSMEs in each regional cluster. The results of the study concluded that not many MSMEs, especially in East Java understood the nature of sharia accounting. Most only have heard but never carried out Islamic accounting. This is certainly an interesting fact because even Muslim entrepreneurs do not understand what sharia accounting is.

"We are trying to obey the rule of the Qur'an in business management, even though it's not enough to be called as an Islamic accounting practice" (N1)

"Islamic accounting is basically just ordinary accounting, right? But given additional zakat?" (N2)

"To be honest, the concept of Islamic accounting is interesting, but we lack knowledge" (N3)

Several things that cause sharia accounting are not grounded among East Java Muslim entrepreneurs are (1) lack of knowledge and information related to sharia accounting; (2) the absence of specific guidelines related to the application of special MSME sharia accounting; and (3) there are still many Muslim entrepreneurs who do not understand the urgency and benefits of sharia accounting.

We often hear what is Islamic accounting is, but the practice is difficult, most of the training from the government is about conventional accounting" (N4)

"I am a graduate of accounting; at the time I was in college I often studied PSAK and SAK ETAP for MSMEs but never knew there were specific sharia accounting guidelines for MSMEs" (NI)

"Our discussion regarding sharia accounting is interesting, but unfortunately there are not many fellow Muslim entrepreneurs who understand the urgency and benefits" (N2)

\subsection{Grounding Islamic Accounting}

Based on the results of the FGD with representatives of Muslim business associations in East Java, it can be concluded that there is a need for a media to ground the use of sharia accounting. One such media is the guidelines for the implementation of sharia accounting specifically for MSMEs. Before preparing the guidelines, observations will be made of accounting transactions that occur in the daily MSME business processes. Transactions are then used as a basis for making sharia accounting guidelines. This is done so that the guidelines are right on target and in accordance with the needs of MSMEs.

"I think if there is a sharia accounting module or manual it will be easier for us to practice" (N3)

"If there really are such guidelines, of course, I welcome it. I am very enthusiastic about studying sharia accounting "(N1)

The accounting shariah guideline contains rules and examples of MSME transactions presented in the Islamic accounting standard. In these guidelines, also explained the terms in Islamic accounting and the time of its use. As a complement, sharia accounting guidelines specifically for MSMEs also contain verses of the Qur'an related to transactions that occur. This guideline is expected to be a window of knowledge and information for SMEs related to the comprehensive implementation of Islamic accounting. In addition, this guideline will also be socialized to MSMEs by means of regular training and assistance both online and offline. In this assistance, MSMEs will be guided to be able to understand and practice the contents of 
the guidelines. Through this preparation and assistance, it is expected that MSMEs can improve the quality of financial management through sharia accounting that is oriented towards Divine values.

\section{Conclusion}

Islamic accounting basically does not only measure monetary value but also the value of spirituality. This makes sharia accounting very important in business management because it is able to encourage someone to be honest and trustworthy. Based on this, this study tries to map the pattern of the use of Islamic accounting at MSMEs, especially in East Java. Through data collected by interviews and focus group discussions, this study concludes that MSME Muslim entrepreneurs in East Java do not understand what sharia accounting is and it is still difficult to practice it in financial management. This condition occurs due to the absence of guidelines that are able to describe sharia accounting practices in real terms at MSMEs. The results of the study suggest that it is necessary to develop a guideline model of sharia accounting practices according to the conditions of MSMEs.

\section{References}

[1] R. M. Ayyub, "Exploring perceptions of non-Muslims towards Halal foods in UK," Br. Food J., 2015.

[2] M. Battour, F. Hakimian, M. Ismail, and E. Boğan, "The perception of non-Muslim tourists towards halal tourism," J. Islam. Mark., 2018.

[3] S. Sadeeqa, A. Sarriff, I. Masood, F. Saleem, and M. Atif, "Knowledge, Attitude, and Perception Regrading Halal Pharmaceuticals among General Public in Malaysia," IJPHS Int. J. Public Heal. Sci., vol. 2, no. 4, pp. 143-150, 2013.

[4] Y. A. Aziz and N. V. Chok, "The role of Halal awareness, Halal certification, and marketing components in determining Halal purchase intention among non-Muslims in Malaysia: A structural equation modeling approach," J. Int. Food Agribus. Mark., vol. 25, no. 1, pp. 1-23, 2013.

[5] T. Reuters, Special Release: IT 18-2 and GST 18-2: Explanatory (technical) Note to the Budget Implementation Act, 2018, No. 1 (March 22, 2018 Notice of Way and Means Motion, Now in Bill C-74): Income Tax Act and Regulations, Excise Tax Act, excise Act, 2001 and Related Legislation. Thomson Reuters, 2018.

[6] P. Biancone and M. Mohamed Radwan Ahmed Salem, "Sharia compliant "possibility for Italian SMEs," 2014.

[7] H. S. Alim, "Global ill-literacies: Hip hop cultures, youth identities, and the politics of literacy," Rev. Res. Educ., vol. 35, no. 1, pp. 120-146, 2011.

[8] I. Triyuwono, "So, What is Sharia Accounting?," IMANENSI J. Ekon. Manajemen, dan Akunt. Islam, vol. 1, no. 1, pp. 42-50, 2013.

[9] Y. C. Pratama and A. Azzis, "Macroeconomic Variables, International Islamic Indices, and The Return Volatility in Jakarta Islamic Index,” Al-Iqtishad J. Islam. Econ., vol. 10, no. 1, pp. 171$188,2017$.

[10] L. G. Zucker, "Institutional theories of organization,” Annu. Rev. Sociol., vol. 13, no. 1, pp. 443464, 1987.

[11] T. J. Fogarty, "The imagery and reality of peer review in the US: Insights from institutional theory," Accounting, Organ. Soc., vol. 21, no. 2-3, pp. 243-267, 1996.

[12] S. Indonesia, "Badan pusat statistik," BPS Republik Indones., 2016.

[13] J. Salmons, Qualitative online interviews: Strategies, design, and skills. Sage Publications, 2014. 
[14] B. Suyanto, Sosiologi Ekonomi: Kapitalisme dan Konsumsi di Era Masyarakat PostModernisme. Jakarta: Kencana, 2013.

[15] J. W. Webb, G. D. Bruton, L. Tihanyi, and R. D. Ireland, "Research on entrepreneurship in the informal economy: Framing a research agenda," J. Bus. Ventur., vol. 28, no. 5, pp. 598-614, 2013.

[16] C. Elgin and F. Erturk, "Informal economies around the world: measures, determinants and consequences," Eurasian Econ. Rev., vol. 9, no. 2, pp. 221-237, 2019.

[17] L. A. Perguna, I. H. Al Siddiq, and Irawan, "Desa Membangun UMKM: Pendampingan UMKM berbasis Village Driven Development dalam Penguatan Ekonomi Warga Di Desa Gogodeso Kabupaten Blitar," Engagem. J. Pengabdi. Kpd. Masy., vol. 3, no. 2, pp. 217-230, 2019.

[18] Y. Kumar, G. Pandey, A. P. W. Wordsworth, and J. S. Chauhan, Reflecting on India's development: Employment, skill and health. Springer Singapore, 2018.

[19] T. T. H. Tambunan, "The Indonesian Experience with Two Big Economic Crises," Mod. Econ., 2010.

[20] L. Martínez, J. R. Short, and D. Estrada, "The urban informal economyStreet vendors in Cali, Colombia," Cities, vol. 66, pp. 34-43, 2017.

[21] M. Athaide and H. K. Pradhan, "A model of credit constraint for MSMEs in India," Small Bus. Econ., no. 2018, 2019.

[22] C. C. Williams, "Entrepreneurship, the informal economy and rural communities," $J$. Enterprising Communities, vol. 5, no. 2, pp. 145-157, 2011.

[23] R. Madjid, "Dampak Kegiatan Pedagang kaki Lima (PKL) Terhadap Lingkungan di DKI Jakarta," J. Ekon., vol. 1, no. 3, 2013.

[24] Areeza and Tauran, "Evaluasi Kebijakan Penataan PKL di Sentra PKL Manukan Lor Kota Surabaya," J. Kaji. Kebijak. Publik, vol. 1, no. 1, 2016.

[25] V. A. Onodugo, N. H. Ezeadichie, C. A. Onwuneme, and A. E. Anosike, "The dilemma of managing the challenges of street vending in public spaces: The case of Enugu City, Nigeria," Cities, vol. 59, pp. 95-101, 2016.

[26] N. Zainun, "Depresi Ekonomi Dunia 1929-1935: Perubahan Dasar Ekonomi, Hala Tuju Dan Involusi Pertanian Di Pulau Jawa,” EKUITAS (Jurnal Ekon. dan Keuangan), vol. 10, no. 1, p. $105,2017$.

[27] C. Geertz, Involusi Pertanian: Proses Perubahan Ekologi Di Indonesia. Bhratara, 1976.

[28] I. H. Al Siddiq, M. Saputra, and S. Untari, "Rural Industrialization And The Impact On Citizens (The Shifting Of Agricultural Land Using In Henri Lefebvre's Space Perspective)," in Advances in Social Science, Education and Humanities Research (ASSEHR), 2019, vol. 313, pp. 285-289.

[29] E. Sadewo, "Dampak Post-Suburbanisasi dan Pertumbuhan Perkotaan di Kawasan Pinggiran Metropolitan Jabodetabek Terhadap Kerentanan Bencana Banjir," J. Green Growth dan Manaj. Lingkung., 2018.

[30] C. Elgin and C. Oyvat, "Lurking in the cities: Urbanization and the informal economy," Struct. Chang. Econ. Dyn., vol. 27, pp. 36-47, 2013.

[31] A. Wibowo and E. P. Kurniawati, "Pengaruh Penggunaan Informasi Akuntansi Terhadap Keberhasilan Usaha Kecil Menengah (Studi Pada Sentra Konveksi di Kecamatan Tingkir Kota Salatiga)," J. Ekon. dan Bisnis, vol. 18, no. 2, p. 107, 2016.

[32] A. D. Rothenberg, A. Gaduh, N. E. Burger, C. Chazali, I. Tjandraningsih, R. Radikun, C. Sutera, and S. Weilant, "Rethinking Indonesia's Informal Sector," World Dev., vol. 80, pp. 96-113, 2016. 